\title{
Increased bone morphogenetic protein-6 in follicular fluid and granulosa cells may correlate with fertilization and embryo quality in humans
}

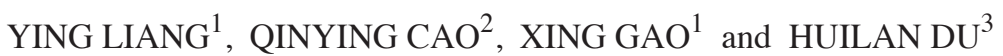 \\ ${ }^{1}$ Reproductive Medicine Center; ${ }^{2}$ Prenatal Diagnosis Center, Shijiazhuang Obstetrics and Gynecology Hospital, \\ Shijiazhuang, Hebei 050011; ${ }^{3}$ Department of Integrated Traditional and \\ Western Medicine, Hebei University of Chinese Medicine, \\ Shijiazhuang, Hebei 050091, P.R. China
}

Received May 5, 2016; Accepted March 31, 2017

DOI: $10.3892 /$ etm.2017.4603

\begin{abstract}
Bone morphogenetic protein-6 (BMP-6), which is a member of the transforming growth factor- $\beta$ superfamily, is associated with the regulation of bone development and various physiological processes. In the present study, the expression of BMP-6 in follicular fluid and granulosa cells (GCs) from pregnant and non-pregnant patients was explored. A total of 44 pregnant patients (pregnant group) and 36 non-pregnant patients (non-pregnant group) were recruited for the present study. The expression of BMP-6 was detected using western blotting and reverse transcription-quantitative polymerase chain reaction. The expression of BMP-6 was significantly higher at the protein level $(\mathrm{P}<0.01)$ in follicular fluid obtained from the pregnant group compared with that from the non-pregnant group. The mRNA and protein expression of BMP-6 in GCs were significantly upregulated in the pregnant group compared with the non-pregnant group (both $\mathrm{P}<0.01)$. These results suggest that high expression of BMP-6 in pregnant women may be a novel biomarker for the fertility process.
\end{abstract}

Correspondence to: Dr Ying Liang, Reproductive Medicine Center, Shijiazhuang Obstetrics and Gynecology Hospital, 206 East Zhongshan Road, Shijiazhuang, Hebei 050011, P.R. China

E-mail: ying_liangen@hotmail.com

Dr Huilan Du, Department of Integrated Traditional and Western Medicine, Hebei University of Chinese Medicine, 326 South Xinshi Road, Shijiazhuang, Hebei 050091, P.R. China

E-mail: duhuilan@163.com

Abbreviations: GCs, granulosa cells; BMP-6, bone morphogenetic protein-6

Key words: bone morphogenetic protein-6, granulosa cells, follicular fluid, pregnancy, in vitro fertilization-embryo transfer

\section{Introduction}

Mammalian oocyte growth and development depends on a functional two-way communication axis between oocytes and ovarian granulosa cells (GCs) (1-5). The cellular and molecular mechanisms associated with this process are poorly understood, but communication between oocytes and GCs are able to form a paracrine signaling pathway via soluble oocyte-secreted factors (OSFs) $(6,7)$. This communication is essential for oocyte developmental competence. Examples of OSFs include bone morphogenetic protein (BMP)-15, BMP-6 and growth differentiation factor (GDF)-9, which are produced in ovarian follicles (8).

BMPs, which are a subfamily of the transforming growth factor- $\beta$ superfamily, are produced by mammalian oocytes $(9,10)$. In addition to its effect on the regulation of bone development, accumulating data suggest that the BMP signaling pathway also serves a key role in the process of ovarian follicle development (11-13). Blocking the BMP signaling pathway in mouse GCs has previously been demonstrated to impair female fertility and to induce breast cancer progression (14-16).

BMP- 6 is one of the BMP ligands that are produced by mammalian oocytes, GCs and other cell types $(9-11,17,18)$. Researchers have identified various functions of BMP-6 in the ovaries, such as inducing decreases in FSH receptor, inhibin- $\alpha$, and inhibin/activin $\beta$ subunit mRNA expression in rat GCs (19) and increasing inhibin- $\alpha$ and activin- $\alpha$ production in bovine GCs (20). The regulation of activins and FSH receptor is crucial during folliculogenesis $(21,22)$; therefore, these findings provided a rationale to investigate the roles of BMP- 6 in human oocyte development. To the best of our knowledge, whether BMP-6 is important for oocyte quality and associated with pregnancy outcomes following in vitro fertilization (IVF) had not been previously assessed. Therefore, to define the reproductive function of BMP-6 in vivo, the present study was conducted to compare the gene and protein expression levels of BMP-6 in vivo in follicular fluid and in GCs between pregnant and non-pregnant patients following IVF and embryo transfer. 


\section{Materials and methods}

Study design. The Ethics Committee of Shijiazhuang Obstetrics and Gynecology Hospital (Shijiazhuang, China) approved the present methodology and all patients gave their informed consent, prior to participation. Furthermore, the study protocol followed the principles of the Declaration of Helsinki. In total, 80 female patients who were recruited to the Reproductive Medicine Center, Shijiazhuang Obstetrics and Gynecology Hospital, between September 2012 and July 2014 for the present study and subsequently underwent intracytoplasmic sperm injection (ICSI). A total of 44 patients

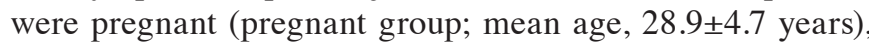
and 36 patients were not pregnant (non-pregnant group; mean age, 29.4 \pm 3.8 years) based on pregnancy outcomes, assessed according to serum hCG levels measured 14 days after embryo transfer. The inclusion criteria for all patients included: Previous treatment for ovarian stimulation, age $\leq 38$ years and a basal follicle-stimulating hormone (bFSH) level $<10 \mathrm{IU} / \mathrm{l}$. The exclusion criteria included the following: The inability to bear pregnancy due to severe diseases; severe psychiatric disorders; urinary system infection; sexually transmitted infections; a previous history of drug and/or alcohol abuse; a teratogenic level of exposure to X-ray radiation; endometriosis; uterine cavity lesions, including endometrial polyps and intrauterine adhesions; and other factors, including endometrial infertility.

Treatment. Both groups underwent long-term gonadotropin-releasing hormone $(\mathrm{GnRH})$ downregulation. All patients were administered $0.1 \mathrm{mg} /$ day Triptorelin (Ipsen Pharma Biotech S.A.S., Z.E. de Signes, France) intramuscularly, which is a GnRH agonist, prior to the mid-luteal phase of menstruation for $\geq 14$ days until patients met the study criteria: Endometrium, $\leq 5 \mathrm{~mm}$ by ultrasonic testing $(23,24)$; serum estradiol $\left(\mathrm{E}_{2}\right),<50 \mathrm{pg} / \mathrm{ml}$ by chemiluminiscence method, as previously described (25). Patients were then administered gonadotropins [(Gn) 250-300 IU recombinant human follitropin alfa solution for injection (Gonal-F; Merck Serono; Merck KGaA, Darmstadt, Germany)] daily for 9-12 days via abdominal subcutaneous injection to advance follicle growth. The duration of $\mathrm{Gn}$ was associated with the different ovary responses to $\mathrm{Gn}$ for each individual. During Gonal-F administration, the rate of follicular development was monitored via ultrasound examination and the levels of $\mathrm{E}_{2}$, progesterone $(\mathrm{P})$, and luteinizing hormone ( $\mathrm{LH})$ were measured using the chemiluminiscence method to regulate the dose of Gonal-F to generate a follicular diameter $\geq 18 \mathrm{~mm}$ in both ovaries. The dosage of gonadotropin $(\mathrm{Gn})$ used was calculated by multiplying the $\mathrm{Gn}$ dosage by the number of Gn days. The use of Gonal-F and Triptorelin was stopped on the evening of the same day and $250 \mu \mathrm{g}$ human chorionic gonadotrophin (hCG; Merck Serono; Merck KGaA) was administered via intramuscular injection. After 36-38 h, fertilized eggs were harvested via ultrasound-guided transvaginal puncture oocyte retrieval surgery (26). Following oocyte retrieval surgery, a selected oocyte-corona-cumulus complex was placed into a $\mathrm{CO}_{2}$ incubator at $37^{\circ} \mathrm{C}$, cultured for 4-6 h.

On day 3 after fertilization, the cleavage and embryo quality was observed, embryo quality was classified as follows: Grade 1, uniform cell size, 0 or $<5 \%$ debris; grade 2, the majority of cells exhibited characteristics of the stage of 6-9 cells on day 3 embryonic development, fragments of $10-25 \%$ or grade 3 , the cells are different, blastomere size uneven, $>25 \%$ fragments. Grade 1 and grade 2 embryos were classed as high quality embryos, as previously described (27).

Preparation of sperm. The corresponding husbands (aged from 22-40 years old) all provided signed informed consent. On the oocyte retrieval surgery day, ejaculated spermatozoa were obtained by masturbation following 3-5 days of ejaculatory abstinence. After liquefaction of semen at room temperature, sperm samples were prepared by discontinuous density-gradient centrifugation. For discontinuous density-gradients, the bottom fraction was aspirated and washed with Quinn's sperm wash medium (ART-2040, SAGE; BioPharma, Trumbull, CT, USA) twice at $300 \mathrm{x}$ g for $20 \mathrm{~min}$ at room temperature and incubated at $37^{\circ} \mathrm{C}$ until use.

Collection of follicular fluid and GCs. Following oocyte retrieval, the collected follicular fluid was transferred to a centrifuge tube for separation at $4^{\circ} \mathrm{C}(125 \mathrm{xg} ; 5 \mathrm{~min})$, and the supernatant was stored at $-80^{\circ} \mathrm{C}$ until required. The remaining fluid was discarded, and PBS was added to bring the volume of the sediment to $5 \mathrm{ml}$. Subsequently, $5 \mathrm{ml}$ human lymphocyte separation medium (Beijing Solarbio Science \& Technology Co., Ltd., Beijing, China) was placed in another centrifuge tube, into which the PBS-sediment sample was added slowly via a straw. The sample was then centrifuged at $4^{\circ} \mathrm{C}$ with $80 \mathrm{x} \mathrm{g}$ for $20 \mathrm{~min}$. When a layer of white GCs was observed in the middle of the tube, granular cell centrifugation at $4^{\circ} \mathrm{C}$ was performed at $503 \times \mathrm{g}$ for $5 \mathrm{~min}$. The supernatant was subsequently discarded and the granular cells were flash frozen in liquid nitrogen and stored at $-80^{\circ} \mathrm{C}$ until required.

Reverse transcription-quantitative polymerase chain reaction $(R T-q P C R)$. Total RNA was isolated from GCs with TRIzol reagent (Invitrogen; Thermo Fisher Scientific, Inc., Waltham, MA, USA) according to the manufacturer's protocol. cDNA was synthesized according to the manufacturers instructions of the M-MLV First Strand kit (Thermo Fisher Scientific, Inc.). qPCR of mRNA was performed according to the manufacturer instructions of the Platinum SYBR-Green qPCR Super Mix UDG kit (Invitrogen; Thermo Fisher Scientific, Inc.) on an ABI 7300 system (Thermo Fisher Scientific, Inc.). A GAPDH endogenous control was used for normalization, and the relative amount of mRNA was calculated using the $2^{-\Delta \Delta \mathrm{CA}}$ method (28). The primers used were as follows: BMP-6, forward, 5'-GCAATCTGTGGGTTGTGACT-3' and reverse, 5'-AAGGGCTGCTTGTCGTAAG-3'; and GAPDH forward, 5'-TGAACGGGAAGCTCACTGG-3' and reverse, 5'-GCT TCACCACCTTCTTGATGTC-3'. The PCRs were performed in $20 \mu \mathrm{l}$ reaction volumes with $10 \mathrm{X}$ PCR buffer, $25 \mathrm{mM}$ $\mathrm{MgCl}_{2}, 25 \mathrm{mM}$ dNTPs, $1 \mu \mathrm{l}$ primers and $0.5 \mathrm{U}$ AmpliTaq Gold (4311816; Applied Biosystems; Thermo Fisher Scientific, Inc.). PCR was performed as follows: $95^{\circ} \mathrm{C}$ for $10 \mathrm{~min}$ followed by 40 cycles of $95^{\circ} \mathrm{C}$ for $5 \mathrm{sec}$ and $60^{\circ} \mathrm{C}$ for $1 \mathrm{~min}$. All samples were assessed in triplicate and the value of the cycle threshold (CT) was determined using ABI 7500 software (Applied Biosystems; Thermo Fisher Scientific, Inc.). 
Table I. Patient infertility characteristics according to pregnancy status.

\begin{tabular}{|c|c|c|c|c|}
\hline Group & $\begin{array}{c}\text { Patients, } \\
\mathrm{n}\end{array}$ & $\begin{array}{l}\text { Age, } \\
\text { years }\end{array}$ & $\begin{array}{c}\text { Infertility } \\
\text { duration, } \\
\text { years }\end{array}$ & $\begin{array}{c}\mathrm{bFSH}, \\
\text { IU/l }\end{array}$ \\
\hline Non-pregnant & 36 & $29.4 \pm 3.8$ & $5.2 \pm 3.7$ & $4.6 \pm 2.7$ \\
\hline Pregnant & 44 & $28.9 \pm 4.7$ & $4.6 \pm 2.1$ & $5.8 \pm 4.0$ \\
\hline P-values & & 0.608 & 0.364 & 0.129 \\
\hline
\end{tabular}

Values are presented as the mean \pm standard deviation. Age, infertility duration, and basal follicle-stimulating hormone.

Western blot analysis. Lysates from follicular fluid and GCs were prepared with $150 \mathrm{mM} \mathrm{NaCl}, 50 \mathrm{mM}$ Tris- $\mathrm{HCl}(\mathrm{pH} 7.5)$, $1 \%$ Nonidet P-40, $0.5 \%$ sodium deoxycholic acid, and complete protease inhibitor mixture tablets (Roche Applied Science, Penzberg, Germany), and protein was then isolated as previously described $(29,30)$. A total of $10 \mathrm{ng}$ protein from each sample were separated by $10 \%$ SDS-PAGE and electrotransfered to a PVDF membrane (EMD Millipore, Billerica, MA, USA). Membranes were blocked with $5 \%$ milk for $2 \mathrm{~h}$ at room temperature and incubated overnight at $4^{\circ} \mathrm{C}$ using the following primary antibodies: Rabbit anti-rat BMP-6 (1:1,000; cat no. ab155963; Abcam, Cambridge, UK) and mouse anti-rat $\beta$-actin (1:1,000; cat no. sc-130656; Santa Cruz Biotechnology, Inc., Dallas, TX, USA). Membranes were subsequently incubated with horseradish peroxidase-conjugated secondary antibody (1:10,000, cat no. 611-1302; Rockland) for $2 \mathrm{~h}$ at room temperature and then evaluated with an ECL (enhanced chemiluminescence) Fusion Fx (Vilber Lourmat, Marne-la-Vallée, France). Images were captured and processed using Quantity One software, version 4.62 (Bio-Rad Laboratories, Inc.). All experiments were replicated three times.

Immunofluorescence staining. GCs were performed on coverslips fixed at room temperature for $15 \mathrm{~min}$ in 50:50 methanol:acetone. Sections were deparaffinized with xylene and rehydrated in a graded ethanol series (from 70, 80, 90 to and $100 \%$ absolute ethyl alcohol), the slides were pre-incubated at room temperature for 30 min with $10 \%$ normal goat serum (cat no. 710027, KPL; SeraCare Life Sciences Inc., Milford, MA, USA) and then incubated with primary antibodies BMP-6 (1:50; cat no. ab155963; Abcam) at $4^{\circ} \mathrm{C}$ overnight. The secondary antibodies were fluorescein-labeled rabbit IgG antibody (1:200; cat no. 021516; KPL; SeraCare Life Sciences Inc.) at room temperature for $30 \mathrm{~min}$. In each experiment, DAPI (cat no. 157574; MB Biomedicals, LLC., Santa Ana, CA, USA) was used for nuclear counter staining. Images were acquired using a Leica microscope (DM6000B) and digitized using LAS version 4.4 software (both from Leica Microsystems, Wetzlar, Germany).

Statistical analysis. Data analysis was conducted using SPSS 13.0 software (SPSS, Inc., Chicago, IL, USA). All data are presented as the mean \pm standard deviation. Differences between groups were assessed using Student's t-test or one-way

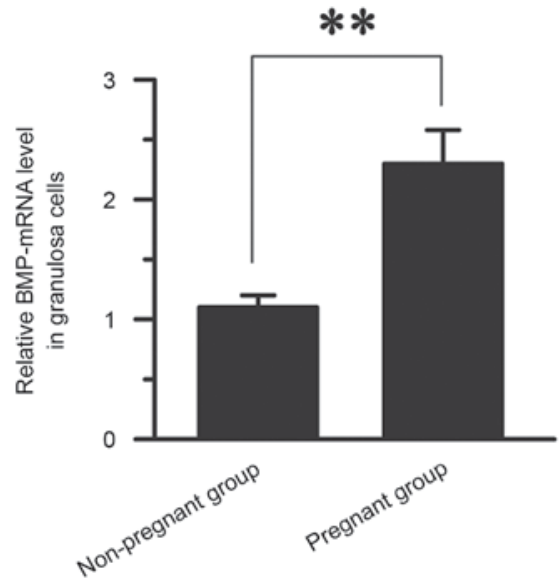

Figure 1. Comparison of BMP-6 mRNA expression in GCs between pregnant and non-pregnant patients. The level of GC BMP-6 mRNA in the pregnant group was significantly higher than that observed in the non-pregnant group. ${ }^{* *} \mathrm{P}<0.01 ; \mathrm{n}=3$. BMP, bone morphogenetic protein; GC, granulosa cell.

analysis of variance. $\mathrm{P}<0.05$ was considered to indicate a statistically significant difference.

\section{Results}

General conditions and treatment. A total of 80 female patients who underwent ICSI were recruited for the present study. The inclusion criteria for all patients included a long protocol for ovarian stimulation, age $\leq 38$ years, and a bFSH level <10 IU/l. Age, duration of infertility, and bFSH levels did not differ significantly between the pregnant and non-pregnant groups (Table I).

The dosage of Gn used, and the serum $\mathrm{E}_{2}, \mathrm{LH}$ and $\mathrm{P}$ levels on the day of hCG administration were compared, and no significant differences were observed between the two groups (Table II).

The number of oocytes was also compared, and no significant differences were observed between groups (Table III); however, the fertilization rate and the high quality embryo rate were significantly higher in the pregnant group compared with the non-pregnant group $(\mathrm{P}<0.01$; Table III).

Comparison of BMP-6 mRNA expression in GCs between pregnant and non-pregnant patients. RT-qPCR was used to compare the mRNA levels of BMP-6 in GCs between pregnant and non-pregnant patients. The expression of BMP-6 mRNA in the pregnant group $(2.30 \pm 0.28)$ was significantly higher than that observed in the non-pregnant group $(1.10 \pm 0.10$; $\mathrm{P}<0.01$; Fig. 1).

Comparison of BMP-6 protein expression in follicular fluid between pregnant and non-pregnant patients. The level of BMP-6 protein in follicular fluid between pregnant and non-pregnant patients was compared. Follicular fluid was collected from 36 patients in the non-pregnant group and 44 patients in the pregnant group. The protein expression level of BMP-6, as determined by western blot, are presented in Fig. 2. The protein expression level of BMP-6 was significantly higher in follicular fluid from the pregnant group $(0.93 \pm 0.06)$ than in follicular fluid from the non-pregnant group $(0.47 \pm 0.11 ; \mathrm{P}<0.01$; Fig. 1$)$. 
Table II. Patients' controlled ovarian hyperstimulation parameters according to pregnancy status.

\begin{tabular}{|c|c|c|c|c|c|}
\hline \multirow[t]{2}{*}{ Group } & \multirow[t]{2}{*}{ Patients, n } & \multirow[t]{2}{*}{$\begin{array}{l}\text { Total dose } \\
\text { of Gn, IU }\end{array}$} & \multicolumn{3}{|c|}{$\begin{array}{l}\text { Serum level on day } \\
\text { of hCG administration }\end{array}$} \\
\hline & & & $\mathrm{E}_{2}, \mathrm{pg} / \mathrm{ml}$ & $\mathrm{LH}, \mathrm{mIU} / \mathrm{ml}$ & $\mathrm{P}, \mathrm{ng} / \mathrm{ml}$ \\
\hline Non-pregnant & 36 & $2868 \pm 958$ & $4757 \pm 1745$ & $0.81 \pm 0.43$ & $0.91 \pm 0.58$ \\
\hline Pregnant & 44 & $3038 \pm 832$ & $4529 \pm 2005$ & $1.00 \pm 0.72$ & $0.89 \pm 0.71$ \\
\hline P-values & & 0.389 & 0.594 & 0.168 & 0.892 \\
\hline
\end{tabular}

Values are presented as the mean \pm standard error of the mean. Gn, gonadotropin; hCG, human chorionic Gn; $\mathrm{E}_{2}$, estradiol; LH, luteinizing hormone; P, progesterone.

Table III. Patient indexes of clinical treatment according to pregnancy status.

\begin{tabular}{|c|c|c|c|c|}
\hline Group & Patients, n & Oocytes, $\mathrm{n}$ & $\begin{array}{c}\text { Fertilization rate, } \% \\
\text { (fertilized/unfertilized) }\end{array}$ & $\begin{array}{c}\text { Rate of good } \\
\text { quality embryos }(\%)\end{array}$ \\
\hline Non-pregnant & 36 & $14.6 \pm 6.2$ & $58.6(269 / 461)$ & $34.4(106 / 308)$ \\
\hline Pregnant & 44 & $15.3 \pm 4.8$ & $82.1(345 / 420)^{\mathrm{a}}$ & $55.3(166 / 300)(166 / 300)^{\mathrm{a}}$ \\
\hline P-values & & 0.571 & $<0.0001^{\mathrm{a}}$ & $0.0002^{\mathrm{a}}$ \\
\hline
\end{tabular}

Oocytes are presented as the mean \pm standard error of the mean. Fertilization rate is presented as ratio of fertilized oocytes to total oocytes; and rate of good quality embryos is presented as ratio of good quality embryos to total embryos. ${ }^{\text {a }}<0.01$ vs. non-pregnant group.

A

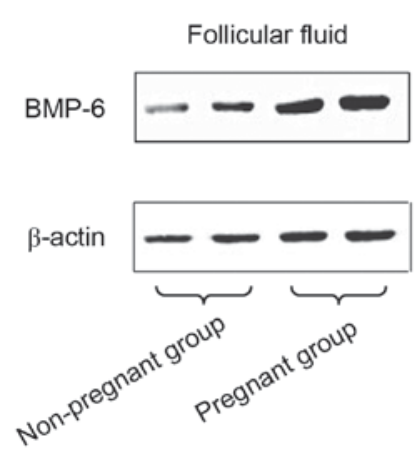

B

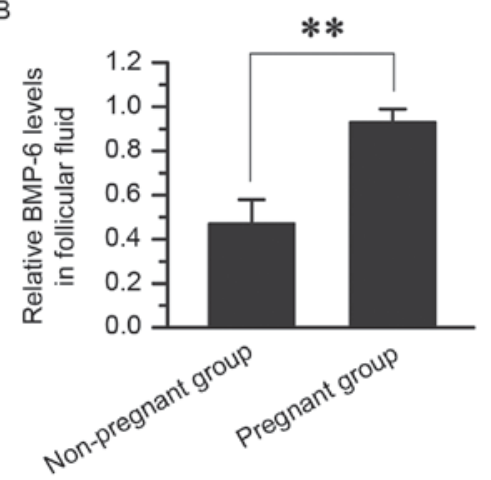

Figure 2. Comparison of BMP-6 protein expression in the follicular fluid between the pregnant and non-pregnant groups. (A) Western blot results concerning the expression of BMP-6 protein in follicular fluid. (B) Analysis of western blotting. The BMP-6 protein level was normalized based on the level of $\beta$-actin protein. The level of follicular fluid BMP-6 in the pregnant group was significantly higher than that observed in the non-pregnant group. ${ }^{* *} \mathrm{P}<0.01 ; \mathrm{n}=3$. BMP, bone morphogenetic protein.

Comparison of BMP-6 protein expression in GCs between pregnant and non-pregnant patients. The expression of BMP-6 protein in GCs was compared between pregnant and non-pregnant patients. GCs were collected from 36 patients in the non-pregnant group and 44 patients in the pregnant group. The protein expression of BMP-6, as determined via western blotting, is presented in Fig. 3. The protein expression level of BMP-6 was significantly higher in GCs from the pregnant group $(0.94 \pm 0.16)$ than in GCs from the non-pregnant group $(0.76 \pm 0.01 ; \mathrm{P}<0.01 ;$ Fig. 3$)$. The expression and distribution of BMP- 6 protein in GCs between the pregnant and non-pregnant groups was also compared using immunofluorescence staining (Fig. 4). The level of BMP-6 was significantly higher in the pregnant group $(99.6 \pm 66.8)$ than in the non-pregnant group (56.2 $\pm 30.8 ; \mathrm{P}<0.01 ; \mathrm{n}=3$; Fig. 4$)$.

\section{Discussion}

In the present study, intrafollicular granulosa-lutein cell BMP-6 mRNA and protein expression was detected in patients undergoing IVF-embryo transfer treatment, which indicated that BMP-6 may serve a role in folliculogenesis during ovarian hyperstimulation. Based on the BMP-6 expression results obtained for follicular fluid and granular cells, it was demonstrated that BMP-6 expression was significantly higher in the pregnant group compared with the non-pregnant. However, 
A

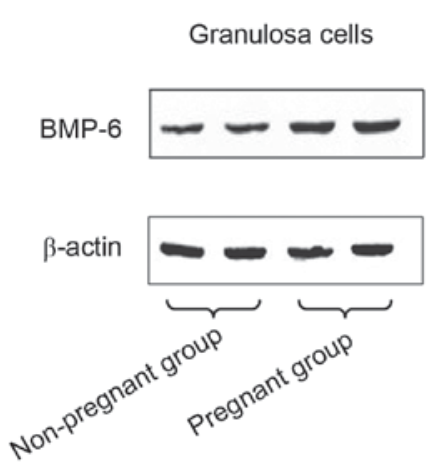

B

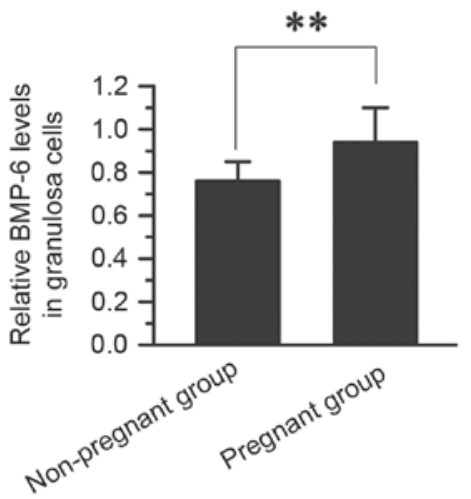

Figure 3. Comparison of BMP-6 protein expression in GCs between the pregnant and non-pregnant groups. (A) Western blot results concerning the expression of the BMP-6 protein in GCs. (B) Analysis of western blotting. The BMP-6 protein level was normalized based on the level of $\beta$-actin protein. The level of GC BMP-6 in the pregnant group was significantly higher than that observed in the non-pregnant group. ${ }^{* *} \mathrm{P}<0.01 ; \mathrm{n}=3$. BMP, bone morphogenetic protein; GC, granulosa cell.

A

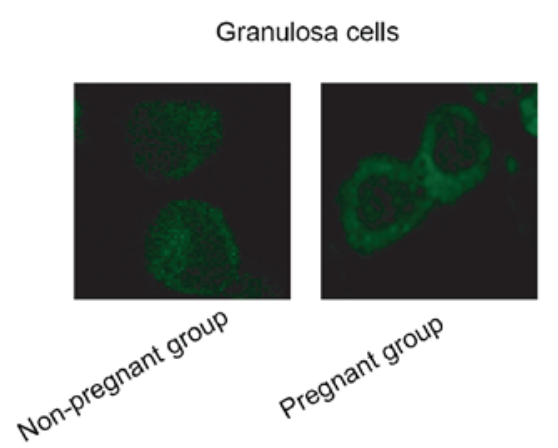

B

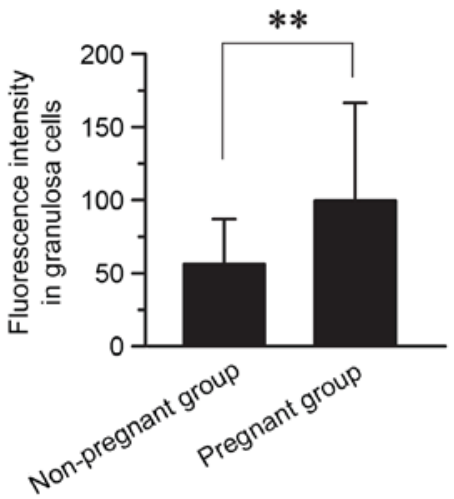

Figure 4. Comparison of BMP-6 protein levels and distribution in GCs between the pregnant and non-pregnant groups via immunofluorescence. (A) Representative images of BMP-6 in GCs from each group. (B) Analysis of immunofluorescence. The level of GC BMP-6 was significantly higher in the pregnant group than in the non-pregnant group. ${ }^{* *} \mathrm{P}<0.01 ; \mathrm{n}=3$. BMP, bone morphogenic protein; GC, granulosa cell.

no additional statistically significant correlations were identified between BMP-6 expression and the number of oocytes, the number of transferred embryos, the fertilization rate or the clinical pregnancy rate. The obtained results suggest that BMP-6 expression in the human ovary may serve a role in oocyte maturation. Appropriate expression of BMP-6 may be associated with good oocyte quality in IVF cycles.

Folliculogenesis is the process by which primordial follicles grow and develop to the ovulatory follicle stage. Previous studies have investigated BMP-6, BMP-15 and GDF-9 expression during folliculogenesis. Species differ widely in the initiation of follicle growth. Mice with null mutations in the BMP-6 and BMP-15 genes undergo normal follicle development and have normal fertility (31). Conversely, mutations in the BMP-15 gene are associated with infertility in sheep and premature ovarian failure in humans $(32,33)$. Other studies have demonstrated that BMP-6 is associated with follicle growth in the pre-antral and antral stages $(34,35)$. In addition, some studies have demonstrated that BMP-15 and GDF-9 are able to stimulate granulosa cell mitosis in pre-antral follicles $(12,31,36)$. During selection of the dominant follicle, the growth of small pre-antral follicles is impaired by restricting androgen output from theca cells. Granulosa-derived activin and BMP-6 and oocyte-derived GDF-9, BMP-15 and BMP-6 are associated with this process. These factors may attenuate the output of LH-dependent androgen by theca cells in small pre-antral follicles (13).

In addition, BMP- 6 protein was strongly expressed in the GCs of healthy tertiary follicles and weakly expressed in the GCs of atretic follicles. BMP-6 increased the expression of anti-mullerian hormone, preserving the ovarian reserve. This research indicated that BMP-6 serves an important role during this period (11).

In addition to promoting ovulation and inhibiting premature luteinization, BMP-6, BMP-15 and GDF-9 also inhibit premature luteinization and limit progesterone biosynthesis by suppressing progesterone synthesis (37). Following ovulation, these oocyte-derived luteinization inhibitors are lost. In addition, BMP-6 may increase the accumulation of neutrophils in the ovulatory follicle and suppress the effect of protease inhibitors (35). Accordingly, it is essential to investigate the molecular aspects of folliculogenesis in future clinical applications. The findings of the present study suggested that BMP-6 may be associated with fertilization and embryo quality in humans. Therefore, BMP-6 may become a useful marker in IVF procedures; however, further research must be done on this topic.

Taken together, these findings suggest important paracrine and autocrine roles for BMP-6 in the regulation of ovarian functions. To the best of our knowledge, the present study 
provides the first evidence of an autocrine role for BMP-6 in the regulation of oocyte quality.

\section{Acknowledgements}

The present study was supported by the National Natural Science Foundation of China (grant no. 81173294).

\section{References}

1. Buccione R, Vanderhyden BC, Caron PJ and Eppig JJ: FSH-induced expansion of the mouse cumulus oophorus in vitro is dependent upon a specific factor(s) secreted by the oocyte. Dev Biol 138: 16-25, 1990

2. Eppig JJ, Wigglesworth K, Pendola F and Hirao Y: Murine oocytes suppress expression of luteinizing hormone receptor messenger ribonucleic acid by granulosa cells. Biol Reprod 56: 976-984, 1997

3. Gilchrist RB, Ritter LJ and Armstrong DT: Mouse oocyte mitogenic activity is developmentally coordinated throughout folliculogenesis and meiotic maturation. Dev Biol 240: 289-298, 2001.

4. Salustri A, Yanagishita M and Hascall VC: Mouse oocytes regulate hyaluronic acid synthesis and mucification by FSH-stimulated cumulus cells. Dev Biol 138: 26-32, 1990.

5. Vanderhyden BC, Telfer EE and Eppig JJ: Mouse oocytes promote proliferation of granulosa cells from preantral and antral follicles in vitro. Biol Reprod 46: 1196-1204, 1992.

6. Li R, Norman RJ, Armstrong DT and Gilchrist RB: Oocyte-secreted factor(s) determine functional differences between bovine mural granulosa cells and cumulus cells. Biol Reprod 63: 839-845, 2000

7. Eppig JJ, Wigglesworth K and Pendola FL: The mammalian oocyte orchestrates the rate of ovarian follicular development. Proc Natl Acad Sci USA 99: 2890-2894, 2002.

8. McNatty KP, Moore LG, Hudson NL, Quirke LD, Lawrence SB Reader K, Hanrahan JP, Smith P, Groome NP, Laitinen M et al: The oocyte and its role in regulating ovulation rate: A new paradigm in reproductive biology. Reproduction 128: 379-386, 2004.

9. Elvin JA, Yan C and Matzuk MM: Oocyte-expressed TGF-beta superfamily members in female fertility. Mol Cell Endocrinol 159: 1-5, 2000

10. Paradis F, Novak S, Murdoch GK, Dyck MK, Dixon WT and Foxcroft GR: Temporal regulation of BMP2, BMP6, BMP15, GDF9, BMPR1A, BMPR1B, BMPR2 and TGFBR1 mRNA expression in the oocyte, granulosa and theca cells of developing preovulatory follicles in the pig. Reproduction 138: 115-129, 2009.

11. Shi J, Yoshino O, Osuga Y, Koga K, Hirota Y, Hirata T, Yano T, Nishii $\mathrm{O}$ and Taketani Y: Bone morphogenetic protein- 6 stimulates gene expression of follicle-stimulating hormone receptor, inhibin/activin beta subunits, and anti-Mullerian hormone in human granulosa cells. Fertil Steril 92: 1794-1798, 2009.

12. Shimasaki S, Moore RK, Otsuka F and Erickson GF: The bone morphogenetic protein system in mammalian reproduction. Endocr Rev 25: 72-101, 2004.

13. Knight PG and Glister C: TGF-beta superfamily members and ovarian follicle development. Reproduction 132: 191-206, 2006.

14. Yi SE, LaPolt PS, Yoon BS, Chen JY, Lu JK and Lyons KM: The type I BMP receptor BmprIB is essential for female reproductive function. Proc Natl Acad Sci USA 98: 7994-7999, 2001.

15. Edson MA, Nalam RL, Clementi C, Franco HL, Demayo FJ, Lyons KM, Pangas SA and Matzuk MM: Granulosa cell-expressed BMPR1A and BMPR1B have unique functions in regulating fertility but act redundantly to suppress ovarian tumor development. Mol Endocrinol 24: 1251-1266, 2010.

16. Du J, Yang S, An D, Hu F, Yuan W, Zhai C and Zhu T: BMP-6 inhibits microRNA-21 expression in breast cancer through repressing deltaEF1 and AP-1. Cell Res 19: 487-496, 2009.

17. Solloway MJ, Dudley AT, Bikoff EK, Lyons KM, Hogan BL and Robertson EJ: Mice lacking Bmp6 function. Dev Genet 22: 321-339, 1998

18. Lyons KM, Pelton RW and Hogan BL: Patterns of expression of murine Vgr-1 and BMP-2a RNA suggest that transforming growth factor-beta-like genes coordinately regulate aspects of embryonic development. Genes Dev 3: 1657-1668, 1989.
19. Otsuka F, Moore RK and Shimasaki S: Biological function and cellular mechanism of bone morphogenetic protein- 6 in the ovary. J Biol Chem 276: 32889-32895, 2001.

20. Glister C, Kemp CF and Knight PG: Bone morphogenetic protein (BMP) ligands and receptors in bovine ovarian follicle cells: Actions of BMP-4, -6 and -7 on granulosa cells and differential modulation of Smad-1 phosphorylation by follistatin. Reproduction 127: 239-254, 2004.

21. Yamoto $\mathbf{M}$, Minami S, Nakano $\mathrm{R}$ and Kobayashi $\mathrm{M}$ : Immunohistochemical localization of inhibin/activin subunits in human ovarian follicles during the menstrual cycle. J Clin Endocrinol Metab 74: 989-993, 1992.

22. Minegishi T, Tano M, Igarashi M, Rokukawa S, Abe Y, Ibuki Y and Miyamoto K: Expression of follicle-stimulating hormone receptor in human ovary. Eur J Clin Invest 27: 469-474, 1997.

23. Ata B and Tulandi T: Ultrasound automated volume calculation in reproduction and in pregnancy. Fertil Steril 95: 2163-2170, 2011.

24. Corbacioğlu A and Baysal B: Effects of endometrial thickness and echogenic pattern on assisted reproductive treatment outcome. Clin Exp Obstet Gynecol 36: 145-147, 2009.

25. Zhang F, Liu XL, Rong N and Huang XW: Clinical value of serum anti-mullerian hormone and inhibin $\mathrm{B}$ in prediction of ovarian response in patients with polycystic ovary syndrome. J Huazhong Univ Sci Technolog Med Sci 37: 70-73, 2017.

26. Wu YT, Wang TT, Chen XJ, Zhu XM, Dong MY, Sheng JZ, $\mathrm{Xu} \mathrm{CM}$ and Huang HF: Bone morphogenetic protein-15 in follicle fluid combined with age may differentiate between successful and unsuccessful poor ovarian responders. Reprod Biol Endocrinol 10: 116, 2012.

27. Alpha Scientists in Reproductive Medicine and ESHRE Special Interest Group of Embryology: The Istanbul consensus workshop on embryo assessment: Proceedings of an expert meeting. Hum Reprod 26: 1270-1283, 2011.

28. Livak KJ and Schmittgen TD: Analysis of relative gene expression data using real-tie quantitative PCR and the 2(-Delta Delta C(T)) method. Methods 25: 402-408, 2001.

29. Wu YT, Tang L, Cai J, Lu XE, Xu J, Zhu XM, Luo Q and Huang HF: High bone morphogenetic protein-15 level in follicular fluid is associated with high quality oocyte and subsequent embryonic development. Hum Reprod 22: 1526-1531, 2007.

30. Otsuka F, Yao Z, Lee T, Yamamoto S, Erickson GF and Shimasaki S: Bone morphogenetic protein-15. Identification of target cells and biological functions. J Biol Chem 275: 39523-39528, 2000.

31. Yan C, Wang P, DeMayo J, DeMayo FJ, Elvin JA, Carino C, Prasad SV, Skinner SS, Dunbar BS, Dube JL, et al: Synergistic roles of bone morphogenetic protein 15 and growth differentiation factor 9 in ovarian function. Mol Endocrinol 15: 854-866, 2001.

32. Galloway SM, McNatty KP, Cambridge LM, Laitinen MP, Juengel JL, Jokiranta TS, McLaren RJ, Luiro K, Dodds KG, Montgomery GW, et al: Mutations in an oocyte-derived growth factor gene (BMP15) cause increased ovulation rate and infertility in a dosage-sensitive manner. Nat Genet 25: 279-283, 2000

33. Di Pasquale E, Beck-Peccoz P and Persani L: Hypergonadotropic ovarian failure associated with an inherited mutation of human bone morphogenetic protein-15 (BMP15) gene. Am J Hum Genet 75: 106-111, 2004.

34. Araújo VR, Silva GM, Duarte AB, Magalhães-Padilha DM, Almeida AP, Lunardi FO, Serafim MK, Moura AA, Campello CC, Rodrigues AP and Figueiredo JR: Bone morphogenetic protein-6 (BMP-6) stimulates the antrum formation by the regulation of its signalling pathway in caprine pre-antral follicles cultured in vitro. Reprod Domest Anim 51: 59-68, 2016.

35. Akiyama I, Yoshino O, Osuga Y, Shi J, Takamura M, Harada M, Koga K, Hirota Y, Hirata T, Fujii T, et al: The role of bone morphogenetic protein 6 in accumulation and regulation of neutrophils in the human ovary. Reprod Sci 21: 772-777, 2014.

36. Paulini F and Melo EO: The role of oocyte-secreted factors GDF9 and BMP15 in follicular development and oogenesis. Reprod Domest Anim 46: 354-361, 2011.

37. Otsuka F, Moore RK, Iemura S, Ueno N and Shimasaki S: Follistatin inhibits the function of the oocyte-derived factor BMP-15. Biochem Biophys Res Commun 289: 961-966, 2001. 